\title{
SLC1A3 variant associated with hemiplegic migraine and acetazolamide-responsive MRS changes
}

\author{
Martin Paucar, MD, PhD, Tobias Granberg, MD, PhD, Kristina Lagerstedt-Robinson, PhD, \\ Elisabet Waldenlind, MD, PhD, Sven Petersson, PhD, Love Nordin, PhD, and Per Svenningsson, MD, PhD
}

Neurol Genet 2020;6:e474. doi:10.1212/NXG.0000000000000474

Familial hemiplegic migraine (FHM) is a group of rare familial disorders caused, in most cases, by mutations in CACNA1A and ATP1A2. ${ }^{1}$ Heterozygous mutations in solute carrier family 1 member 3 (SLC1A3), encoding glial glutamate transporter, are associated with episodic ataxia type 6 (EA6). ${ }^{2-5}$ In addition to episodic ataxia (EA), alternating hemiplegia and hemiplegic migraine have been reported twice in patients with EA6. ${ }^{2,4}$ Mutations in SLC1A3 are very rare; screenings in cohorts of EA and alternating hemiplegia have yielded either negative results ${ }^{3,6-8}$ or variants of unclear significance..$^{\mathrm{e}-1-\mathrm{e}-3}$ Herein, we characterize a patient featuring sporadic hemiplegic migraine (SHM) responsive to acetazolamide (ACZ) and mild cerebellar atrophy associated with a new variant in SLC1A3. We also report the utility of proton magnetic resonance spectroscopy (MRS) for this condition.

\section{Methods}

The index case and her mother (figure e-1, doi:10.5061/dryad.v41ns1rsd) were evaluated after providing oral and written consent for this study, which was approved by the Regional Ethics Committee of Stockholm. Patients underwent clinical evaluation, structural imaging with MRI, and genotyping. The index case underwent neurophysiologic tests and proton MRS before and after treatment with ACZ. MRS was also performed in 20 healthy controls (data available from Dryad [appendix, doi:10.5061/dryad.v41ns1rsd]).

\section{Results}

\section{Patient II:1}

The index case is a female 24-year-old medical student with roots in the Middle East and born to consanguineous parents. She was diagnosed with polycystic ovarian syndrome. She was affected by recurrent episodes of left-side hemiplegic spells triggered often by menstruation but also by stress and preceded by a sensorimotor march. Only occasionally these spells affected the right side. Onset was at age 18 years; those episodes occurred twice per year and lasted for up to 2 hours. On one occasion, she had hemiparesis for 9 hours; migraine without aura preceded the hemiplegia spells by 1 to 2 days. The patient did not have any visual complaints during the attacks either; she reported numbness in the hemiparetic side during the entire hemiplegic episode. Examination during 1 episode that motivated admission demonstrated left-sided hemiparesis but normal visual fields and absence of ataxia. The patient did not have any visual complaints during the attacks either; however, any visual aura may well have disappeared by the time she came to the hospital. Interictally, the patient had gaze-evoked nystagmus (GEN), and EEG and electroneurography

\author{
Correspondence \\ Dr. Paucar \\ martin.paucar-arce@sll.se
}



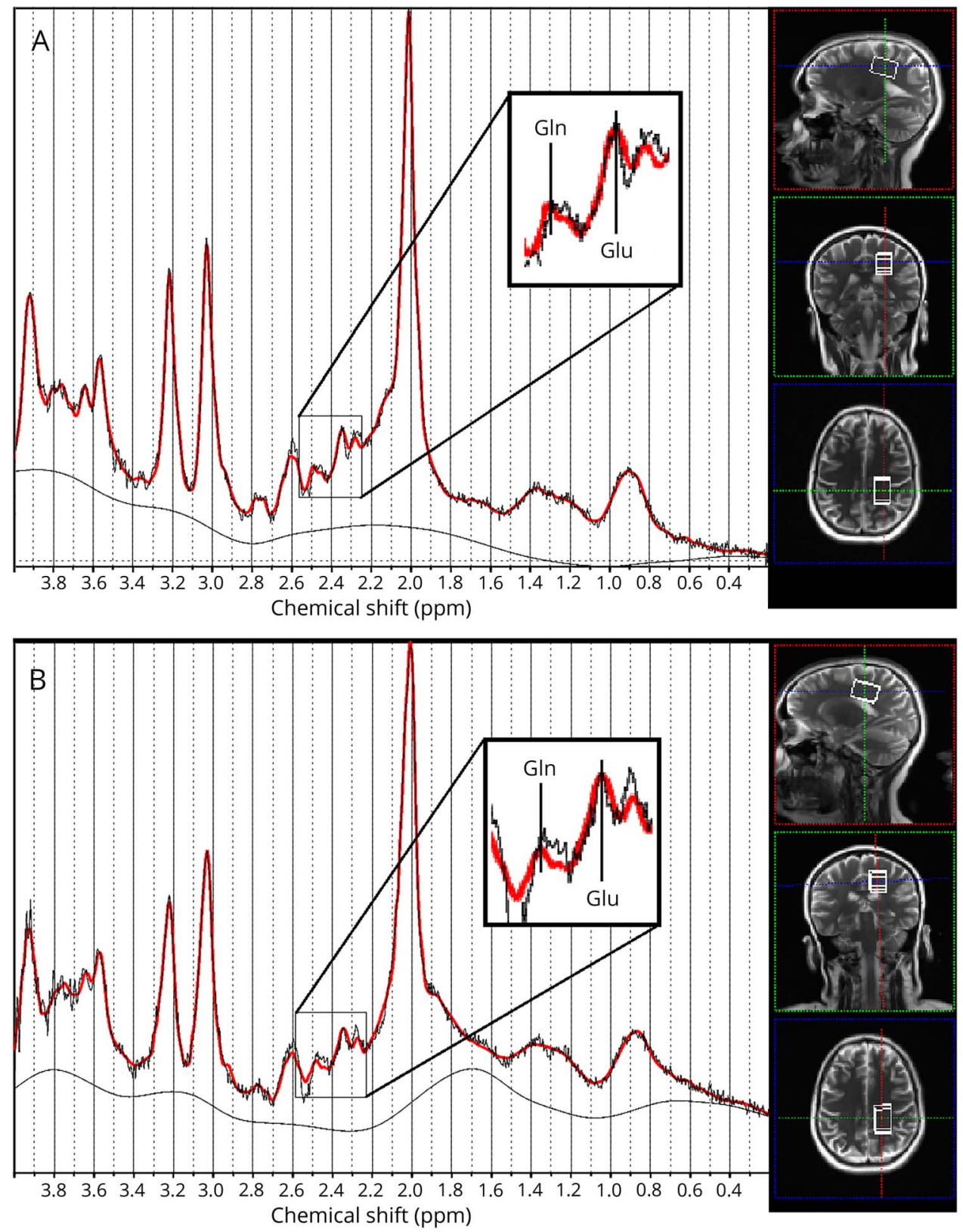

The T2-weighted images to the right show the location of a $30 \times 20 \times$ $20 \mathrm{~mm}$ volume of interest in a midsagittal, coronal, and transverse plane. The described voxel was averaged 200 times, and the resulting ${ }^{1} \mathrm{H}$-MR spectrum is displayed to the left where the main peaks for glutamine and glutamate have been highlighted. In the first measurement, $A$, the Glx concentration was measured to $3.865 \mathrm{mmoL} / \mathrm{kg}$ (SD $10 \%$ ) in the left frontoparietal region. In the second measurement, B, Glx concentration was measured to $4.580 \mathrm{mmoL} / \mathrm{kg}$ (SD 11\%).

were normal. Pathologic CAG expansions in CACNA1A and conventional mutations in CACNA1A, ATP1A2, and SCN1A were ruled out. A targeted analysis revealed the novel variant c379_383del in SLC1A3. This sequence variant leads to a truncating protein (p.Tyr127Aspfs*60) and is absent in databases (The Genome Aggregation Database [gnomAD], ClinVar, and The Human Gene Mutation Database). Other sequence variants leading to haploinsufficiency are otherwise rare in the normal population (gnomAD). Treatment with ACZ (250 mg twice daily) prevented hemiplegic spells and interictal GEN receded. This therapeutic benefit has lasted for more than 1.5 years, and the patient decided to interrupt this treatment to avoid polypharmacy. MRI of her brain demonstrated mild vermian atrophy (figure e-2, doi:10.5061/dryad.v41ns1rsd). The index case went through MRS during an interictal period before and after treatment with ACZ (figure 1). MRS demonstrated low Glx (combined glutamate and glutamine) peak $(3.865 \mathrm{mmol} / \mathrm{kg}, \mathrm{SD} 10 \%)$ and nominally higher levels $(4.580$ $\mathrm{mmol} / \mathrm{kg}$, SD $11 \%$ ) in the parietal lobe after treatment with ACZ was initiated (data available from Dryad: doi:10.5061/ dryad.v41ns1rsd [table e-2, doi:10.5061/dryad.v41ns1rsd]). At age 23 years, the proband developed Cushing syndrome due to an adrenocortical carcinoma, which motivated a right-side nephrectomy and adrenalectomy. Further investigation revealed 2 lung metastases that were resected; recently, one of these metastases has relapsed. 


\section{Patient I:1}

This patient is a 50-year-old woman who meets the criteria for migraine with visual aura ${ }^{\mathrm{e}-4}$ but denies hemiplegic and ataxia episodes. Her examination and brain MRI were normal; she declined MRS and neurophysiologic tests (table e-1, doi:10. 5061/dryad.v41ns1rsd).

\section{Discussion}

Hemiplegic migraine in association with a SLC1A3 variant has not been reported before to the best of our knowledge. Despite mild cerebellar atrophy, only interictal nystagmus was found in the index case. Of note, penetrance was reduced in our family; the parent carrying the variant has migraine, which was also reported for the variants p.Cys186Ser and p.Trp387Pro. ${ }^{3,4}$ The long latency between onset of SHM and Cushing syndrome strongly argues against a paraneoplastic syndrome. A correlation between the degree of glutamate reuptake and clinical severity has been suggested, ${ }^{3}$ but the theoretical haploinsufficiency in our family challenges that hypothesis. A dominant negative effect has been demonstrated for the variants p.Pro290Arg, whereas a clear loss of function was described for p.Trp387Pro. ${ }^{2,4}$ Similar to our case, large deletions in CACNA1A cause EA 2 possibly by means of haploinsufficiency. ${ }^{\mathrm{e}-5}$ De Fusco et al. proposed a similar mechanism in FHM2. ${ }^{\mathrm{e}-6}$ Two reported SLC1A3 variants ${ }^{\mathrm{e}-1-\mathrm{e}-3}$ are likely benign considering their frequency in the normal population (gnomAD). Factors modulating variable expressivity and reduced penetrance of SLC1A3 variants are unknown. SLC1A3 is highly expressed in the cerebellum and brainstem, ${ }^{2}$ and the sequence variants described in patients are thus far spread in different domains of the protein. Taken together, our findings demonstrate that $S L C 1 A 3$ variants are associated with a spectrum of disorders similar to those seen in CACNA1A mutations. Our work expands the spectrum of SLC1A3 mutations beyond EA, illustrates the benefit of ACZ for hemiplegic migraine, and the utility of MRS as a biomarker for altered glutamate transport. An increase in Glx by $22 \%$ using MRS was found after treatment, with an acceptable SD for both measurements. Our findings are in contrast with the results reported by Zielman et al. among patients with migraine without aura. ${ }^{\mathrm{e}-7}$ These authors found elevated interictal glutamate levels in the visual cortex. In another study by the same group, $7 \mathrm{~T}^{1} \mathrm{H}$-MRS was used for the first time in a group of 18 patients with FHM1 and FHM2. ${ }^{\mathrm{e}-8}$ This study revealed reduced total $\mathrm{N}$-acetylaspartate and total creatine in the cerebellum, but Glx/total creatine in the occipital lobe was not significantly altered. MRS studies on other patients harboring SLC1A3 variants are needed to evaluate whether a specific pattern of metabolite alterations exists for the disease spectrum associated with this gene.

\section{Acknowledgment}

The authors are grateful to the patients for their kind participation in this study. They thank Dr. Mattias Andréasson for evaluating the index case during a hemiplegic spell.

\section{Study funding}

P. Svenningsson is a Wallenberg Clinical Scholar. M. Paucar's, T. Granberg's, and P. Svenningsson's research is supported by Region Stockholm. M. Paucar obtained funding from the Follin Foundation.

\section{Disclosure}

The authors reports no disclosures. Go to Neurology.org/NG for full disclosures.

\section{Publication history}

Received by Neurology: Genetics December 19, 2019. Accepted in final form May 28, 2020.

\section{Appendix Authors}

\begin{tabular}{|c|c|c|}
\hline Name & Location & Contribution \\
\hline $\begin{array}{l}\text { Martin Paucar, } \\
\text { MD, PhD }\end{array}$ & $\begin{array}{l}\text { Karolinska University } \\
\text { Hospital and Karolinska } \\
\text { Institutet, Stockholm }\end{array}$ & $\begin{array}{l}\text { Revision of the manuscript; } \\
\text { study concept and design; } \\
\text { analysis and interpretation of } \\
\text { data; and study supervision } \\
\text { and coordination }\end{array}$ \\
\hline $\begin{array}{l}\text { Tobias } \\
\text { Granberg, MD, } \\
\text { PhD }\end{array}$ & $\begin{array}{l}\text { Karolinska University } \\
\text { Hospital and Karolinska } \\
\text { Institutet, Stockholm }\end{array}$ & $\begin{array}{l}\text { Acquisition and } \\
\text { interpretation of } \\
\text { neuroimaging data and } \\
\text { revision of the manuscript }\end{array}$ \\
\hline $\begin{array}{l}\text { Kristina } \\
\text { Lagerstedt- } \\
\text { Robinson, PhD }\end{array}$ & $\begin{array}{l}\text { Karolinska University } \\
\text { Hospital and Karolinska } \\
\text { Institutet, Stockholm }\end{array}$ & $\begin{array}{l}\text { Acquisition and } \\
\text { interpretation of genetic } \\
\text { data and revision of the } \\
\text { manuscript }\end{array}$ \\
\hline $\begin{array}{l}\text { Elisabet } \\
\text { Waldenlind, } \\
\text { MD, PhD }\end{array}$ & $\begin{array}{l}\text { Karolinska University } \\
\text { Hospital and Karolinska } \\
\text { Institutet, Stockholm }\end{array}$ & $\begin{array}{l}\text { Interpretation of clinical } \\
\text { data and revision of the } \\
\text { manuscript }\end{array}$ \\
\hline $\begin{array}{l}\text { Sven } \\
\text { Petersson, } \\
\text { PhD }\end{array}$ & $\begin{array}{l}\text { Karolinska University } \\
\text { Hospital, Stockholm }\end{array}$ & $\begin{array}{l}\text { Acquisition and } \\
\text { interpretation of MRS data } \\
\text { and revision of the } \\
\text { manuscript }\end{array}$ \\
\hline $\begin{array}{l}\text { Love Nordin, } \\
\text { PhD }\end{array}$ & $\begin{array}{l}\text { Karolinska University } \\
\text { Hospital and Karolinska } \\
\text { Institutet, Stockholm }\end{array}$ & $\begin{array}{l}\text { Acquisition and interpretation } \\
\text { of MRS data and revision of } \\
\text { the manuscript }\end{array}$ \\
\hline $\begin{array}{l}\text { Per } \\
\text { Svenningsson, } \\
\text { MD, PhD }\end{array}$ & $\begin{array}{l}\text { Karolinska University } \\
\text { Hospital and Karolinska } \\
\text { Institute, Stockholm }\end{array}$ & $\begin{array}{l}\text { Revision of the manuscript; } \\
\text { analysis and interpretation } \\
\text { of data; study supervision } \\
\text { and coordination; and } \\
\text { obtaining funding }\end{array}$ \\
\hline
\end{tabular}

\section{References}

1. Jen JC. Familial Hemiplegic Migraine. In: Adam MP, Ardinger HH, Pagon RA, et al, editors. GeneReviews $^{\circledast}$ [Internet]. Seattle: University of Washington, Seattle; 1993-2019. Available from: www-ncbi-nlm-nih-gov.proxy.kib.ki.se/books/NBK1388/. Accessed May 14, 2015.

2. Jen JC, Wan J, Palos TP, Howard BD, Baloh RW. Mutation in the glutamate transporter EAAT1 causes episodic ataxia, hemiplegia, and seizures. Neurology 2005;65:529-534.

3. de Vries B, Mamsa H, Stam AH, et al. Episodic ataxia associated with EAAT1 mutation C186S affecting glutamate reuptake. Arch Neurol 2009;66:97-101.

4. Kovermann P, Hessel M, Kortzak D, et al. Impaired $\mathrm{K}+$ binding to glial glutamate transporter EAAT1 in migraine. Sci Rep 2017;7:13913.

5. Iwama K, Iwata A, Shiina M, et al. A novel mutation in SLC1A3 causes episodic ataxia. J Hum Genet 2018;63:207-211.

6. de Vries B, Haan J, Stam AH, et al. Alternating hemiplegia of childhood: no mutations in the glutamate transporter EAAT1.Neuropediatrics 2006;37:302-304.

7. Graves TD, Hanna MG. Episodic ataxia: SLC1A3 and CACNB4 do not explain the apparent genetic heterogeneity. J Neurol 2008;255:1097-1099.

8. Pelzer N, Haan J, Stam AH, et al. Clinical spectrum of hemiplegic migraine and chances of finding a pathogenic mutation. Neurology 2018;90:e575-e582.

References e-1 to e- 8 can be accessed via http://doi:10.5061/dryad.v41ns1rsd. 


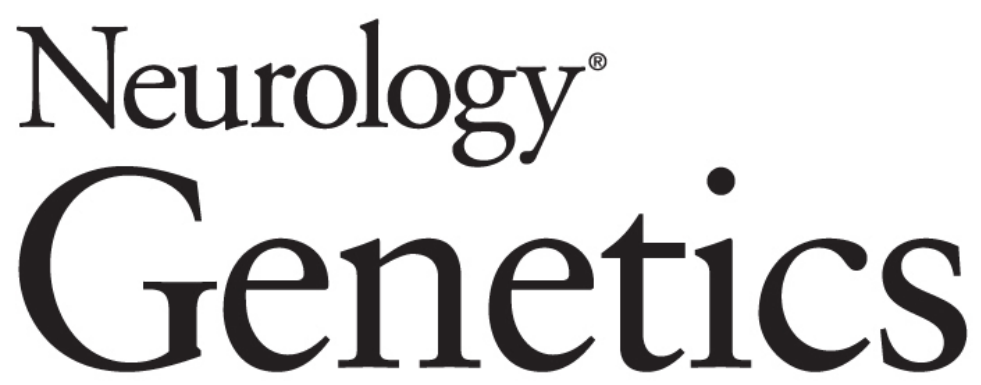

SLC1A3 variant associated with hemiplegic migraine and acetazolamide-responsive MRS changes

Martin Paucar, Tobias Granberg, Kristina Lagerstedt-Robinson, et al.

Neurol Genet 2020;6;

DOI 10.1212/NXG.0000000000000474

This information is current as of July 7, 2020

Neurol Genet is an official journal of the American Academy of Neurology. Published since April 2015, it is an open-access, online-only, continuous publication journal. Copyright Copyright @ 2020 The Author(s). Published by Wolters Kluwer Health, Inc. on behalf of the American Academy of Neurology.. All rights reserved. Online ISSN: 2376-7839.

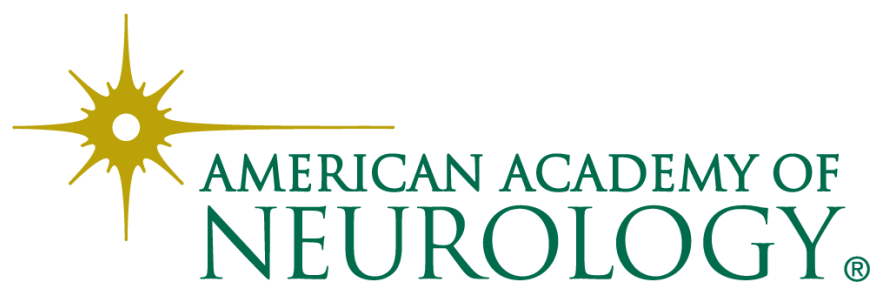




\section{Updated Information \& Services}

\section{References}

Citations

Subspecialty Collections

Permissions \& Licensing

\section{Reprints}

including high resolution figures, can be found at: http://ng.neurology.org/content/6/4/e474.full.html

This article cites 7 articles, 0 of which you can access for free at: http://ng.neurology.org/content/6/4/e474.full.html\#\#ref-list-1

This article has been cited by 2 HighWire-hosted articles: http://ng.neurology.org/content/6/4/e474.full.html\#\#otherarticles

This article, along with others on similar topics, appears in the following collection(s):

\section{All Genetics}

http://ng.neurology.org//cgi/collection/all_genetics Migraine

http://ng.neurology.org//cgi/collection/migraine

MRS

http://ng.neurology.org//cgi/collection/mrs

Information about reproducing this article in parts (figures,tables) or in its entirety can be found online at:

http://ng.neurology.org/misc/about.xhtml\#permissions

Information about ordering reprints can be found online:

http://ng.neurology.org/misc/addir.xhtml\#reprintsus

Neurol Genet is an official journal of the American Academy of Neurology. Published since April 2015, it is an open-access, online-only, continuous publication journal. Copyright Copyright $\odot 2020$ The Author(s). Published by Wolters Kluwer Health, Inc. on behalf of the American Academy of Neurology.. All rights reserved. Online ISSN: 2376-7839.

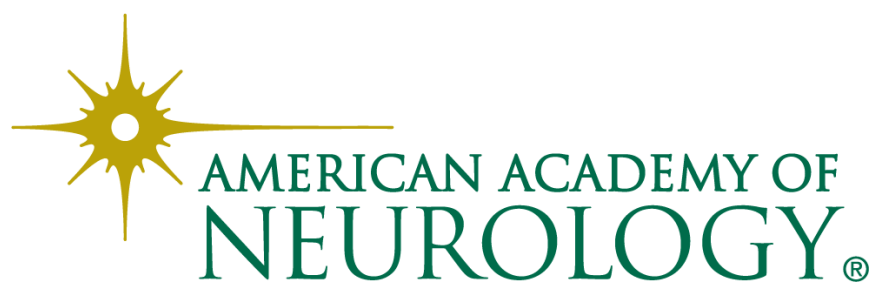

